Rupantaran : A Multidisciplinary Journal

Vol. IV : pp 153-163, October, 2020

ISSN : 2091-0061

https://doi.org/10.3126/rupantaran.v4i1.34212

Research Management Cell (RMC)

Dhankuta Multiple Campus, Dhankuta

Tribhuvan University, Nepal

\title{
Illusion in Equality of Opportunity in Education
}

\author{
Shiva Aryal ${ }^{1}$ \\ Email: shivaaryal66@gmail.com
}

\section{Abstract}

This article focuses on the portion of the confusion that has been addressed by the different sociological and philosophical perspectives on equality of opportunity. For this study, I have used the document review approach where books, reports and research articles are reviewed for the purpose. Basically qualitative information is used and adopted for the thematic information analysis process. This article attempts to settle the illusion of equality of opportunity through binary thinking like the egalitarian that believes on how well people's lives go not just the formally as a support by Marxist view as the protection should have on the basis of socioeconomic position rather than their personal needs. Basic equality and the social democracy theory are concerned on, no one should be discriminated against their sex or gender, race or ethnicity, and socioeconomic background or to be given equal value as a human worth. This article concludes that the illusion of equality of opportunity still remains on which one standard of measurement is best to achieve equal opportunity that one is unanswerable within single pint and events.

Key Words: basic education, condition of equality, egalitarianism, equal opportunity, equality

\section{Introduction}

Equality and equal opportunity are complex concepts, with considerable debate on their meanings and justification. The discussion of equality and discrimination is, in general, characterized by considerable conceptual and methodological confusion. The philosophical debates on equality of opportunity have focused as what aim should be, while we wish to make people more equal (Young, 2001).

Recent debates have shown that the obviously simple question of what we should compare when we make judgments of equality and inequality. The issues are greatly

1. Mr. Aryal is a Lecturer of Foundation of Educaiton at Sanothimi Campus, Bhaktapur, TU, Nepal. 
clarified in the literature but it is not being solved in the practical field. On the other side, it has given little attention to this question about whom (group or individual) we are discussing while we compare people's situation in relation to all of these targets of equality. Universal declaration of Humanrights (1948), article one and two mention as "all human beings are born free and equal in dignity and rights" and all the rights and freedoms set out without any distinction of any kinds." at the same time, the different theory of equality assumes that the unit or elements we should be comparing while we make judgement of inequality are individual.

The International Covenant on Civil and Political Right (1966), article(1), says that all people have the right of self-determination as well as their political right, can freely peruse their economic, social and cultural development, in a way, the convention on the elimination of all forms of discrimination against the women (1979) article (1) states that the discrimination against the women means any distinction made on the basis of sex that focuses on men and women are equally treated in every field of social world. In the same way, the International Convention on the Elimination of All Forms of Racial Discrimination (1965), article (1) suggests that "racial discrimination means an exclusion based on race, color and ethnic origins....". Equal opportunity is an ideal state in which everyone has the same chance to participate and succeed in any aspect of his or her work and life. Our administrative body should guarantee equality of opportunity, but not equality of result. Equality and equal opportunity are complex concepts. Generally people raise the question about lack of women equality with men, old people with younger, people of lower class with higher class, minorities group with privileged group and so on.

Cupit (2006), cited in Aiken \& Haldane (2001) defines the equality with the help of two terms: one is the teleological argument for equality and next is a nonteleological argument for equality; the first is focused on equal achievement of overall pattern of distribution that minimizes the inequalities or increasing in equality that is also supported by social democratic theory ( Thomas, cited in Odekon, 2015). So the people will treat on the principle of equality with certain respects because the inequality is the property that makes the outcomes worse. The second is nonteleological equality where people are equally treated with fundamental sense, to some extent, that will focus on the overall inequalities which must be avoided.

The Government and other authorized organizations obviously legitimate such individual and group, conscious judgment about the equality of opportunity, through the policy and programe like, voting right, educational right, economics right, women right, racial right and so on. Therefore, equality is required for no one should be treated inappropriately. The above argument focuses on the importance of treating appropriately. Here, the concern will be with equality, from which issues as the 
appropriate priority is given to improving the position of the worst off. The ideas of deontological theory have put forth, "people are equals, and make an attempt to claim that people ought to be treated as equals" (McKerlie,1996). On the other hand, even if we accept something is valuable (cast, ethnic, location or relation, preferences, resources or capacity), the question might be raised- why do they give to those people and why don't they give us? what is the rationale behind this?

To frame the discussion, I introduce the two key factors that make illusion for treating people as the notion of equality of opportunity. First, are the people treated as an objective valuation? The equality of opportunity of education, participation in public concern and equality in resources that would significantly influence on each an individual equal achievement in terms of labor market success, preparation for democratic citizenship, and general human successful and, second, that people's life chances should not be fixed by certain morally arbitrary circumstances of their birth such as their social class, race, and gender. But the precise meaning of, and implications for the ideal of equality of educational opportunity is the subject of substantial disagreement. This item provides a critical review of the nature and basis of those disagreements.

The purpose of the article is to analyze the various aspects on the illusion in equality of opportunity. Therefore, it explores the realities on equality of opportunity, outline the benefit of equality of opportunity and to realize the expected barrier related to implementation in equality of opportunity. It also helps to understand the nature of our study through the lenses of literary based information. The equality of opportunity is considered as a popular way for building the justice in society. So, this paper has explored the illusion in equality of opportunity.

\section{Methods and Materials}

This review article adopted the descriptive research methodology to interpret the illusion in equality of opportunities in education. This methodology fundamentally explores and describes the question like- what is an existing situaion of research problem? (Best and Kahn, 2006). The verbal information was explored through the document readings from schoolars' books, research articles and reports. The document study and reviewer introspection were the major sources of information to dig out the delimas and illusion to ensure the equality in eduation. I reviewed the egalitarian theory, basic equality theory, democratic theory, Marxian theory and structural functional theory for getting insights on illusion in equality of opportunities in education. I have consulted website, web-library and library for collecting the documents. After reviewing the literature, I have generated the several themes for analyzing the results. I used the themetic analysis methods for analyzisng the results. 


\section{Results and Discussions}

Based on the findings of this study, the results and discussions have been presented separately, The different theme has been generated from the reviewed theories from different sources of articles and books.

\section{Resutlts}

I reviewed several articles, books and reports to answer the various aspects of illusion of eqaual opportunityes in education. Based on this background information, I generated the different themes which are discussed separately.

\section{Opportunity and education}

Before understanding about the educational opportunity, we need to say what exactly an opportunity is in general. Westen 1990 cited in Christopher (1988) provides a helpful definition of an opportunity that can be applied to the education sphere. For Westen, an opportunity is a relationship between an agent or a set of agents, and a desired goal, mediated by certain obstacles, none of which are impossible For instance, ' $A$ ' is a Dalit student who has an opportunity to become educated mediated by obstacles such as enrolling at a school by the causes of inhabitant in remoteness, poor family background and poor language.

To employ this concept in the context of education, we need to answer questions about who the proper agents are, what the appropriate goal and what are the other obstacles are legitimate. For example, if we take admission at a highly selective college as our goal, and the education institution of any region or any nation as their agent, it will need a certain academic criterion such as passing an entrance exam, able to pay the tuition fee and elite language should be appropriate. To aall, there are relevant obstacles that stand in the way of the goal. In this context, we will also think that an applicant's race, sex or religious affiliation should not be obstacles. When the appropriate group faces only the relevant obstacles with respect to the appropriate goal we can say that equality of opportunity obtains between the members of that group. For instance, 'A' student from Dalit and B from elite culture have equal opportunity to attend a selective university, if all other things being equal, the only obstacle they face is passing an entry test, which is a relevant obstacle. They do not have equal opportunity if A student from Dalit also faces an irrelevant obstacle, such as racebased discrimination, that B student does not face.

\section{Education act and equal opportunity}

Formal equality of opportunity is the view that formal rules that make reference to personal characteristics should not be obstacles to achieving certain goals. Such 
characteristics include race, socio-economic class, gender, religion, and sexuality. It is essentially a concept of equality before the law. It is often understood as an antidiscrimination principle. As applied to educational opportunity, formal equality of opportunity requires the removal of formal obstacles, in the form of laws or entrance criteria for educational institutions, which refer to personal characteristics. Some people accept that formal equality of opportunity is a sufficient norm to guide the distribution of educational opportunities, but most political and moral philosophers accept it as necessary but not sufficient. A principle of non-discrimination leaves open whether and to what extent the state needs to provide the resources that are required for education, or how those resources should be distributed. Since resources are necessary for education- whether in the form of books and materials, teachers, facilities, and so on. Formal equality of opportunity is well-matched with some children failing to receive an education. Formal equality of opportunity fails to provide effective equality of opportunity as suggested by Marx. For Marx, formal equality of educational opportunity is not concerned with the informal rules, social norms, or private discrimination that people in a society face that can have a profound effect on a child's opportunities for education. It is well-suited with school exclusion. Nepal is a country of diversity where people belong to different geographic and ecological areas as well as social, economic, cultural, religious and linguistic groups and sub groups. School is a mini-society, it meant school is a shadow zone of a society which is determined by society and society is separated out by race. Thus, the formal equality of opportunity cannot achieve this goal (Anderson, 2007).

\section{Educational opportunity and merit basis}

The view of meritocratic presumption that educational goods be distributed solely in accordance with individual merit. In the context of education, merit is often measured by entrance requirements, aptitude tests, or grades on exams. It has some limitations, especially with respect to children social condition. If educational opportunities should be given to those who have the most merit in terms of the best scores on entrance tests, we will overlook the fact that merit is endogenous to education, which is to say, educational opportunity itself creates merit (Baker \& Lynch, 2005). The limitation concerning of meritocratic equality of opportunity, first, whether it should be measured based on test scores or to account moral attributes like the ability to work cooperatively with others, and, second is that while conditioning educational opportunities on "merit" may look convincing when dealing with young adults, it is deeply problematic when applied to very young children. As Dworkin (1977) notes, the job of the reading teacher is to teach children to read, not merely to offer the opportunity to learn to read. And this job presumably includes all children in a classroom - even those who are not especially "meritorious". Perhaps this is also 
why the educational "tracking" of very young children on the basis of ability seems especially objectionable - there are certain capacities that need to be cultivated in all children (Mils, 2007).

\section{Equity and educational opportunity}

In the context of limits of formal equality of opportunity, Rawls develop a conception, and is called fair equality of opportunity that requires social workplaces and positions be formally open to all, and that individuals who are similarly talented and motivated should have a roughly equal chance to attain these positions, independent of their social class background (Martin, 1994). It holds that all citizens of a society count as the relevant agents, the desired goal is the workplace and positions, and the obstacles people should not face include their social class background.

When applied to education, this principle may support educational measures that close the achievement gap between the rich and the poor with the same high talent potentials, assuming that these children can be identified. This is because such students from poorer backgrounds should charge as well as their better-off peers with the same potentials. The Rawlsian principle of fair equality of opportunity aims to eliminate the effects of social background and economic class on educational achievement. Fair equality of opportunity therefore offers a radical interpretation of equality of educational opportunity.

Debates on the meaning of equality of opportunity could be derived on the basis of major two aspects: one is diverse goals and measurement of the equality, and, the another is equal opportunity in education that can be achieved when everyone with similar talent gets the same results. The first question is to be considered for the formulation of the diverse goals. All individuals are different in terms of their birth, cast, religion location, gender and socio economic status. Therefore, the major role of the state is to formulate the police regarding to individual's needs and condition.

Liberal democracy theory has advocated to the issues of equality of opportunity in terms of diverse goals and he finds out that the ultimate goals of state is to promote the common good where this is conceived of as promoting the moral, intellectual, and active traits of its citizens as well as all social institution and resources are also used to promote the common good (Stuart, 2007, cited in Baker \& Lynch, 2005).

The second question, here, datable is whether the equal opportunity in goods and services can be achieved when everyone with similar talent gets the same results, when each individual investment is equalized, when those with the same natural talent possible get the same opportunities. Answers to these two fundamental questions enable philosophers to make an idea about equality of opportunity. Rawls worked on 
the criticism of political theory of utilitarianism and he found that the prominent aim of social policy was the maximization of welfare but he opposed, first its aggregative character, unconcerned about the pattern of distribution of welfare and the second objection of this theory is the aspect of a person's condition which advises normative attention. Martin (1994) suggested that the metric of equality or metric of welfare was absolutely powerful but the combination of equality and welfare by primary goods was not correspondingly forceful. He recommended "equality of opportunity for welfare" instead of normative attention.

Sen (1980) has also work on equality of opportunity under the title of capability. It has either welfare nor, it has any rate or welfare alone, he advises that people should have the equality of opportunity to achieve. This view drew the attention to the conditions of people or persons, his thought went beyond Rawls and Mils thought of equality of opportunity for welfare and individual pleasure respectively. As the philosophical controversies, some of these controversies concern clashes with other values, including that of the family and diversity: What restrictions do parental rights put on the search about the equal opportunity? Is positive description is required for or opposing to get equal opportunity?

Marxist view does not accept this view because this process can't be equalizing in result (Katál, 2013). The insight from this meta-analysis is that equality does not indicate a protection of everyone's equality in terms of their personal needs, but the protection of the dominance of social classes or all people of society have to get equal chances to participate in different socioeconomic positions and socialization with the means of production or people have got equal opportunity for enhancing the capacity of individuals. Thus, the meaning of equality of opportunity still remains in illusion.

\section{Discussion}

The aim of this article was to assess the illusion of equal of education by the reflection of egalitarian theory, democratic theory and Marxian's conflict theory of education in the current scenario of basic education in Nepal. The Nepalese society has socially, culturally and ethnically diverse society. The population census report (2011) reported that $80.6 \%$ of the population were Hindus and $10.7 \%$ Buddhists with the remainder being mostly Muslims, Kirats, Christians and Jains. That means the children of the countries have diverse learning needs. To meet this need, we should offer not only access to school but also we have to manage educational opportunity according to their parent language. In this regard, the presumption of the egalitarian theory of equality in education opportunity should be based on equal value of human worth, or the people to all will be treated with equal value. The notion of the theory comes nearby to the assumption of human right. Although the ideas of egalitarians 
do not address the need of children that has created social structure. Even if access to education is ensured, it cannot be said that all children have equal participation in school. Because, the other variables like family background, level of parental education and access in supportive materials directly influence children's teaching and learning. At the same time, Parson argues that the school should represent the society in miniature or opportunity of education should be provided by the principle of achievement rather than ascription. This theory refers to that opportunity of education shouldn't be distributed as said by the egalitarian. Instead that it is provided by the notion of inherent power of individual or level of talent. The application of this theory is in education. The formal education system will be developed the certain standard like entrance exam, previous score of exam and rewarded system and so on that will help to section from the service of basic education.

The assumption of Structural Function theory seems to be useful to eliminate inequalities between naturally acquired abilities among the poor and richer groups, but it cannot be as a complete and appropriate tool to reduce the inequalities of opportunities in basic education. The major idea of this theory is that the duties and responsibilities are provided according to their talent, the level of talent is not only natural but also it depends on nurture (Santrock, 2007). For instance, even, if we give equal chances to both of two children, one is belonging to high class group and another is belonging to lower class of group. In the context of Nepal, the educational achievement is likely to be higher in upper class children than lower class children because the other hidden factors are related to the lower class such as attitude towards education, level of language competency, social environment and reasonable time for education etc. These factors are explicitly influence their education achievement.

The Government Of Nepal (2017) stated that "to transform the lives through education recognizing the important role of education a main driver of development and achieving the other proposed ....". Thus, the provision of equal opportunity in education at basic level by the notion of egalitarian and functional theory is not sufficient in the context of Nepalese society. School Sector Development Program (2016) clearly mentions about the equity of basic education:

To ensure that the education system is inclusive and equitable in terms of access, participation and learning outcomes, with a special focus on reducing disparities among and between groups identified as having the lowest levels of access, participation and learning outcomes.

Marxist view does not accept the above theory because this process can't be equalizing in result (Katál, 2013). For Marx, elite maintains status quo in education system, as upper class has more resources and life chances to benefit the opportunities and quality of education, so the students of these institutions get higher positions in 
examination system and have more chances to get high education and highly paid jobs. In the context of Nepal, the system of education divides into two categories one is private and another is public. The students who are nurtured from the private school, they have got more advanced learning environment and care for them than the students of public school. If we compare the educational achievement, it is found that the educational achievement level of private schools is higher than community schools.

In the view of Marx, the differences in educational achievement also lead to differences in other opportunities like job market. The view of structural functional theory seemed to to be in opposition of Marx's views. For functionalist, market always opens and offers to those people who have merit in rank among the groups. For instance, the Nepalese higher education policy provision by tenth plan in terms of resources management in higher education has said that the resources have been developed through the principle of Cost recover. This principle will be demotivated to intake in higher education from the poor families. Thus, Marx argues that, if the opportunity of education insured on the basis of merit, the children from upper classes become rich and lower classes children become poor too. Bowles and Gintis (2001) support his argument, "Education reproduces the attitudes and behavior for divisions of labor. The gap between the rich and the poor is widening, meaning that education is reproducing more social inequality.

The people who are in exclusion from education service in our society have mainly three reasons: one is relational cause - who they are and how they are related to higher or lower class or dominated groups; another is locational - where they reside? especially, it is centered on physical access (rural, urban, seasonal or permanent); and, the last is situational - that is concerned on social and personal condition. The constitutional provision of education has given equal opportunity of education without any discrimination of caste, religion, language and situation of people and it also emphasizes the free and compulsory education at basic level and even secondary is free.

In this regard, the education policy has been changed and reformed periodically in this line. However, the provision of education service wouldn't be distributed as the principle of fairness or equal opportunity in education. The plan of education like Education for all [EFA] 2001-2015 has indicated that gender parity rate will have reached in one up to 2015, for that purpose, government has attempted to reduce the physical distance from school to home, as well as provision of free text, dress, day tiffin or different education programs like oil of education, food for education and parent empower program with the assumption or principle of democratic theory and Marxist theory. It has cleared that the social, economic, cultural, geographical, 
linguistic and religiously diversify society like Nepal. There is no one single theory better, instead to use better more than one theory in order to equalize opportunities of basic education as well as equalizing in achievement as focused by Max and Rawls.

\section{Conclusion}

The formal equality of opportunity is concerned with the personal characteristics (that include race, socio-economic class, gender, religion, and sexuality) that should not be obstacle to achieving the equal opportunity of education and the distribution of equal opportunity and even other services should be distributed by certain rule. Political and moral philosophers accept it as necessary but not sufficient. The theory of Marx doesn't accept the assumption of formal equality of opportunity. For Marx, equality of opportunity should be based on social norms or private discrimination of individual or family. In contrast, equal distribution of education is solely in accordance with individual merit but at the same time, Rawls's noted an idea and it is called fair equality of opportunity that requires social workplace and position. It would be helpful to address all the people who are similarly talented and motivated. I think it is useful to reduce the gap between poor and richer with the same level of talent but it wouldn't cover the overall inequalities of opportunity.

It can be concluded that, in general, the findings of illusion of equality of opportunity support outcome of previous theoretical assumption, and assessment supports outcome of previous researches. However, while planning interventions to improve in equality of opportunity in education, personal characteristics should be considered as well as the micro level or contextual differences and issues also need to be considered. So, our aim to make happy "people lives", the policy should be made and they should practise under principles of political equality, moral equality and social equality.

\section{References}

Aiken, W. \& Haldane, J. (2001). Philosophy and its public role . United Kingdom: Imprint Academic.

Anderson, E. (N.D). Fair opportunity in education: A democratic equality perspective. Retrieved from: file://C:/Users/user/Downloads/Fair_Opportunity_Education. pdf

Baker. J. \& Lynch. J. (2005). Equality in education: An equality of condition perspective. Dublin: University College Dublin.

Best, J. W. \& Kahn, J. V. (2006). Research in education. New Delhi: PHI learning Pvt. Ltd. 
Bowles, S. and Gintis, H. ( 2001). Schooling in capitalist america revisited. Retrieved from: https://www.umass.edu/preferen/gintis/soced.pdf

Central Beraue of Statistics Nepal (2011). The population census report-2011.

Christopher, J. (1988). "Whom Must We Treat Equally for Educational Opportunity to be Equal?" Ethics, 98 (3), 518-533. doi:10.1086/292969

Dworkin, R. (1977). Taking rights seriously. Cambridge: Harvard University Press.

Government of Nepal (2017). Nepal sustainable development goals: Status and roadmap, 2016-2030. National Planning Commission, Kathmandu: author.

Katál, R. (2013). The concept of equality and well-being in Marx. 16 (1), 47-56.

Martin, R. (1994). Rawls 's new theory of justice. Chi.-Kent L. Rev, 69 (8), 737- 761. Retrieved from: https://core.ac.uk/download/pdf/217422843.pdf

McKerlie, D. (1996) Equality. Retrieved from:https://plato.stanford.edu/entries/

Mils, S.J. (2007). Moral and political philosophy. Retrieved from: https://plato. stanford.edu/entries/mill-moral-politica

Ministry of Education Nepal (2016). Education for all 2001-2015. Kathmandu: UNECSO.

Ministry of Education Nepal, (2016). School sector development plan, Nepal, 2016 2023. Kathmandu.

Odekon, M. (2015). The SAGE encyclopedia of world poverty. Thousand Oaks.

Santrock, J.W. (2007). Adolescentce. New York: Mcgraw-Hill publishing.

Sen, A. K. (1980). 'Equality of what?'. Cambridge: Cambridge University Press.

The United Nations General Assembly. (1965). International convention on the elimination of all forms of racial discrimination.

The United Nations General Assembly. (1966). International covenant on civil and political rights.

The United Nations General Assembly. (1979). Convention on the elimination of all forms of discrimination against women.

The United Nations. (1948). Universal declaration of human rights.

Young, M. I. (2001) Equality of whom: Social groups and judgments of injustice. The Journal of Political Philosophy, 9 (1), 1-4. 